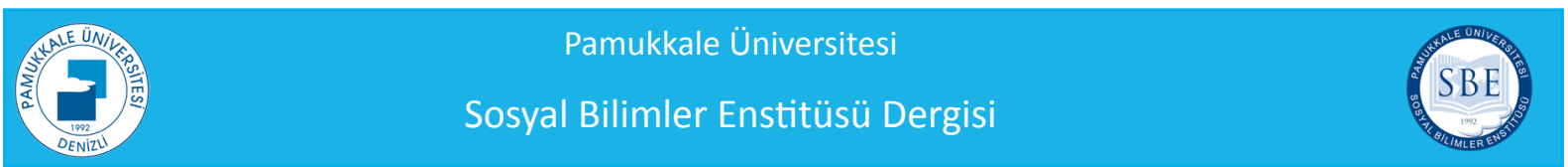

Pamukkale University Journal of Social Sciences Institute

Article Info/Makale Bilgisi

VReceived/Geliş:26.06.2020 VAccepted/Kabul:05.10.2020

DOi:10.30794/pausbed.758470

Araştrrma Makalesi/ Research Article

Ayan, M. ve Yalvaç, F. ( 2021). "Food and Mood in The Particular Sadness of Lemon Cake", Pamukkale Üniversitesi Sosyal Bilimler Enstitüsü Dergisi, Sayı 44, Denizli, ss. 145-158.

\title{
FOOD AND MOOD IN THE PARTICULAR SADNESS OF LEMON CAKE
}

\author{
Meryem AYAN*, Fatma YALVAÇ**
}

\begin{abstract}
The Particular Sadness of Lemon Cake (2010) written by Aimee Bender presents the relation between foods and female moods. Aimee Bender implemented a mixture of real and imagery in her magic realist novel in which the female protagonist, Rose Edelstein, experiences some important changes in her life starting from her ninth birthday. These changes are closely related to food and affect Rose physiologically, psychologically, and emotionally. Rose loves lemon cake and her mother who starts spending most of her time in the kitchen cooks this cake for her ninth birthday. However, Rose feels hollowness aftertaste and feels that her mother is unhappy because she realizes that she can sense the feelings of people from the foods she consumes. Thus, this study aims to reveal the relationship between foods and feelings by analysing Aimee Bender's novel from a postmodern feminist perspective focusing on foods, feelings, gender roles, and female identity.
\end{abstract}

Key Words: Postmodern feminism, Food, Mood, Female, Identity.

\section{THE PARTICULAR SADNESS OF LEMON CAKE ROMANINDA YEMEK VE DUYGU DURUMU}

Öz

Aimee Bender tarafindan yazılan The Particular Sadness of Lemon Cake (2010) isimli roman yiyecekler ve kadınların duyguları arasındaki ilişkiyi göstermektedir. Aimee Bender kadın başkahraman Rose Edelstein'ın dokuzuncu yaş gününden itibaren hayatında bazı önemli değişiklikler yaşamaya başladığı büyülü gerçekçi romanında gerçek ve hayali birbiri ile harmanlamıştır. Bu değişiklikler yiyecekler ile yakından ilişkilidir ve Rose'u fizyolojik, psikolojik ve duygusal olarak etkilemektedir. Rose limonlu keki çok sevmektedir ve zamanının büyük bir kısmını mutfakta geçirmeye başlayan annesi onun için dokuzuncu yaş gününde bu keki yapar. Ancak, Rose'un ağzında kalan tat bir boşluk hissidir ve annesinin mutsuz olduğunu hissetmiştir çünkü artık o tükettiği yiyeceklerden kişilerin duygularını hissedebilmektedir. Buradan hareketle bu çalışma yiyecekler ve duygular arasındaki ilişkiyi Aimee Bender'ın romanını yemekler, duygular, cinsiyet rolleri ve kadın kimliğine odaklanan postmodern feminist bir bakış açısı ile inceleyerek ortaya koymayı amaçlamaktadır.

Anahtar Kelimeler: Postmodern feminism, Yemek, Duygu durumu, Kadın, Kimlik.

\footnotetext{
* Professor Doctor, Manisa Celal Bayar University, Department of English Language and Literature, MANiSA.

e-mail: meryem.ayan@cbu.edu.tr, (https://orcid.org/0000-0003-3138-1523)

** Instructor, Afyon Kocatepe University, Foreign Language Support Unit, AFYONKARAHISAR.

e-mail: ftmyalvac@gmail.com, (https://orcid.org/0000-0001-6978-5705).
} 


\section{FOOD FOR NUTRITION OR FOOD FOR EXPRESSION}

The Particular Sadness of Lemon Cake (2010) written by Aimee Bender is a novel reflecting the relationship between feelings of the female characters and the foods prepared, served, or consumed by the female characters. Aimee Bender's novel is a multi-generic literary work in which the author mingles the magic and reality while presenting the issues closely related to the female characters of the story. A multi-dimensional research framework fits well with the narrative technique of the author who deconstructs the traditional literary pattern through creating a multi-generic literary work. The mixture of real and imagery in the narration process is one of the outstanding points of Aimee Bender's technique that can be defined as a postmodern feminist collage: bits and pieces of female feelings forming the whole of female moods. Considering Aimee Bender's technique implemented in the novel, it can be stated that

disrupting the clarity and certainty of meaning, dehierarchizing binary oppositions, inscribing the difference within, celebrating undecidability ... through such textual strategies as deconstruction, mimicry, parody, pastiche, free association, and so on, are all subversive acts: they denaturalize and expose the illusion of identity and certainty on which the regime of patriarchal representation rests, and they depose the male/phallus from its privileged seat as the primary term, as the One and the Same (Ebert, 1991: 896).

By employing magic realist elements while narrating ordinary daily events, Bender departs from the expectations of classical literary tradition while writing The Particular Sadness of Lemon Cake (2010). As an internationally preferred literary technique, "magic realism" or "magical realism" is "commonly associated with the geographical region of Latin America" (Trivedi, 2013: 392). Among all the Latin American writers, Gabriel Garcia Marquez "is widely considered to be the leading exponent of the literary style known as magical realism" (Trivedi, 2013: 392). Considering the definition of "magic realism" or "magical realism", Trivedi (2013) states that "according to Gabriel Garcia Marquez the term "Magic Realism" means a narrative technique that blurs the distinction between fantasy and reality" (389). Although it has been associated with the Latin American literature, "magic realism has been-convincingly shown to be far more widespread; indeed, in recent decades it has been gaining in international popularity" (Henitiuk, 2003: 410). Bender also contributes to the literary tradition of magic realism, and in The Particular Sadness of Lemon Cake (2010), ordinary events and food-related issues are combined with magical and extraordinary elements. Therefore, the novel can be analysed from changing perspectives which makes this work a distinguishing example for transgressing the borders of classical literature since "magical realist writing aligns itself with the general postmodern view that rejects the existence of only one reality and of only one truth" (Arva, 2008: 77). Bender's narrative technique contributes to the literary tradition of female writers deconstructing the pre-determined literary standards of the male dominated literary tradition. Through magic realism/magical realism, Bender reveals unspoken and hidden feelings of the female characters and portrays an interaction between foods and moods. This interaction is represented through interweaving the real and the magical in the process of expressing the female characters' food related experiences. As it is stated by Trivedi (2013), "the variety of magical occurrences in magic realist writing includes ghosts, disappearances, miracles, extra ordinary talents, vision and strange atmosphere..." (389), and the extra ordinary talent of the protagonist is the magical intervention and the food-related events are the real occurrences of daily life in the novel. The extraordinary ability of the protagonist, Rose, becomes a mundane one since it is a part of Rose's daily life after her ninth birthday. The magic and reality are constantly mingled from beginning till the end of the novel, and the reconciliation of the magical and the real while narrating the food-related experiences of the female characters allows for questioning and transgressing the definitions of patriarchal social norms. Considering this, it can be pointed that "the resistance of magical realism to the narrative authority that Western literature assigned to realism in the nineteenth century has resulted in the questioning of the realistic mode of representation and in the experimentation with new forms of fiction" (Arva, 2008: 77). Namely, the integration of magic into reality while narrating food-related experiences and moods of female characters allows the readers to witness the deconstruction of patriarchal norms regarding the place and role of food and culinary tasks in the lives of female characters. As it is stated by Henitiuk (2003), "if women's experience of reality is of a world where agency is denied them, a space, time, and discourse in which they are rarely accorded access to the structures of power, it should come as no surprise for a feminist author to privilege an alternate sphere that opens up a wider 
range of possibilities" (425). Accordingly, it can be inferred that the alternate sphere for the females where they can have numerous opportunities for agency and self-awareness in The Particular Sadness of Lemon Cake (2010) is the kitchen in which female characters' food-related experiences and feelings are presented with a renewed perspective using magic realism.

In literature, "magical realism provides a special gateway to grasp, if not master, the literary lineaments of postmodernism (or postcolonialism, or both), most particularly due to the ways it is able to subvert or transgress established discursive codes that sustain not only literature but also history" (De La Campa, 1999: 206). On the other hand, "in scholarly circles, the proliferation of critical studies on magic realism that have been generated over the past three quarters of a century, and that continue to get published, points to a similar degree of interest and intellectual curiosity" (Bortolussi, 2003: 279). Accordingly, this study aims to analyse the magic realist novel The Particular Sadness of Lemon Cake (2010) with a postmodern feminist approach because there are lots of coincidences of magic realism and postmodern feminism in the process of revealing the interaction between foods and moods of women in the novel. Bender deconstructs the traditional perspectives regarding cooking and eating that are depicted from a renewed focus emphasising that food is more than nutrition and culinary tasks are not obligatory daily duties in the lives of female characters in the novel. The deconstruction of the role of food-related issues and the plurality of possible meanings obtained in the narrative pattern while analysing the relationship between foods and female moods can be regarded as an important detail in the process of analysing The Particular Sadness of Lemon Cake (2010) from a postmodern feminist perspective. It is seen in the novel that cooking is not an obligatory daily task for the female characters in the novel but a choice for personal relief or professional development. Thus, culinary tasks and food-related issues are beyond the traditional definitions regarding nutrition and women's duties in the kitchen.

Nancy Fraser and Linda Nicholson are among the outstanding critics with their contribution to the discussions related to the postmodern feminism and they assert that postmodernists try "to develop conceptions of social criticism that do not rely on traditional philosophical underpinnings" (Fraser and Nicholson, 1988: 85). The development of the modern conceptions is expected to lead to a postmodern one that would not be limited by the universalist and essentialist considerations of traditional theoretical constructions. On the other hand, they also claim that "feminists, like postmodernists, have sought to develop new paradigms of social criticism that do not rely on traditional philosophical underpinnings" (Fraser and Nicholson, 1988: 91). Although women reject the traditional roles including the ones related to culinary tasks defined by patriarchal social norms in modern feminism, they were limited by the patriarchal limits. However, postmodern feminist thought offers a mixture of the traditional and the modern through which the limits are deconstructed and multiple meanings emerge while analysing literary works narrating stories of female characters. Due to the multiplicity of meanings obtained, the relationship between foods and females' moods revealed through culinary tasks are not limited with the categories of the traditional social norms acknowledging these tasks solely as duties of women. That is to say, each woman has unique experiences and these experiences cannot be put in similar and general frames related to females' lives, and, in this regard, it is stated by Cixous (1976) that "you can't talk about a female sexuality, uniform, homogeneous, classifiable into codes- any more than you can talk about one unconscious resembling another" (876). The diversity and multiplicity of female experiences and perspectives are the issues that postmodern feminism emphasises. As such, in the novel, the female characters' interaction with food-related tasks and culinary experiences are not identically similar with each other. Bender presents changing experiences while depicting the stories of the mother and the daughter in the novel. As a female writer, she portrays the relationship between food and female characters from changing perspectives. Considering this, it can be pointed that "women's imaginary is inexhaustible, like music, painting, writing: their stream of phantasms is incredible" (Cixous, 1976: 876), and Bender's creative literary intervention results in a narration in which patriarchal limits are overcome with matriarchal senses aroused by foods which can be noted as an important point making this novel compatible with the postmodern feminist argument regarding the deconstruction of traditional patriarchal norms limiting women within certain frames.

As it is underlined by Cixous (1976), "the future must no longer be determined by the past" (875), and the traditional considerations regarding the relationship between food and females would be carried beyond the essentialist and foundationalist notions of women's roles in the kitchen defined by patriarchal cultures of the 
past. Moreover, Showalter (1984) emphasizes that "perhaps modern criticism, instead of graciously taking us into its historical embrace, will learn some lessons about itself from our anomalous movement, and will begin to question the myths of its own immaculate conception in the realms of pure and universal thought" (41). In this respect, postmodern feminism becomes part of the effort to approach the issues related to female identity in a way that goes beyond the pre-established universal patriarchal norms and prioritises females' choices and preferences. Accordingly, in postmodern feminist literary studies, cooking seen as a restrictive daily obligation of women is deconstructed and reinterpreted as a creative process, reflecting female moods reconstructed through foods. In this regard, a great number of researches have been carried out by focusing on food and female domestic roles that have been one of the central themes of feminism and postmodernism while analysing female literary texts. The historical development of feminism has been a controversial process due to the fact that feminism has a dynamic interaction with various critical perspectives related to humanity. Terminologically, feminism refers to a movement aiming to ask for equal rights between men and women in political, social, financial, and cultural contexts. Theories and philosophies of feminism are related to the gender difference defined by the patriarchal social structure. As a movement, feminism criticises gender discrimination, campaigns for improving the living standards of women, and defends women's rights and interests. Furthermore, feminism has strived to give voice to the voiceless other marginalised by dominant masculine norms, and "voicing this silenced "other" displaces the dominant logic- dislodging its hegemony and demystifying its "naturalness"- and unleashes an alternative potential" (Ebert, 1991: 888). The focus of feminist literary criticism has been mostly on the experiences of women and also on female social roles reflected in literature. The feminist thought has gone through a development process with the contribution of critics from varying backgrounds, and, accordingly, postmodern feminism has been on the agendas of researchers of different fields. As a comprehensive movement, "postmodernism, a cultural phenomenon that sprang to life in architecture and spread rapidly in to literature, art, and other areas, together with deconstructionism and French feminism, has stimulated and transformed feminist thinking and practices" (Sands and Nuccio, 1992: 489). As a consequence of this transformation, "the most important common ground shared by feminism and postmodernism, and where critics most appear to agree, is the rejection by both movements of the status quo, of dominant systems and in general of the epistemology of the Enlightenment and the anthropocentric definition of the concept of knowledge, logocentrism ..." (Vidal, 1991: 83). Thus, it can be claimed that despite the differences in their focuses while analysing literary works, both postmodernism and feminism reject the pre-established norms drawing the borders of grand-narratives of the past. They also demolish the emphasis given on the binary oppositions that cause the marginalisation of the Other. On the other hand, postmodernism and feminism privilege the importance of diversity and multiplicity of meanings that can be deduced from literary works. Accordingly, The Particular Sadness of Lemon Cake (2010) analysed in this study is open to various interpretations and criticisms. This study focuses on the issues related to foods and feelings of female characters reflected in the novel since these are outstanding literary themes in the process of creating literary works in which female characters and their experiences are depicted.

It is a known fact that food influences individuals physiologically through its nutritional properties. However, it is not limited to a single dimension of people's lives. It can be stated that foods affect people physically, psychologically, emotionally, and socially. In this regard, it is underlined that "people may very well continue to believe that food is an immediate reality (necessity or pleasure), but this does not prevent it from carrying a system of communication; it would not be the first thing that people continue to experience as a simple function at the very moment when they constitute it into a sign" (Barthes, 2013: 25). Thus, it transgresses the preestablished considerations regarding its place for human beings. The interdisciplinary scholarship of food studies and women's studies "encompasses such diverse fields as philosophy, political economy, anthropology, sociology, history, and cultural studies, and the topics addressed range from minute studies of a single food item to close readings of food and its representation as the basis for broad cultural analyses" (Avakian and Haber, 2005: 7). It crosses the borders of imagination and provides deeper meanings also in the literature that can be interpreted through a multidisciplinary lens since "food can serve as a substitute to compensate our emotional, psychological and social desires, imperfections and ambitions" (Varghese, 2018: 434). When the issue is the unspoken feelings and thoughts of female characters in fictional works, foods are implemented as a substitution for words and an instrument for conveying messages related to women's lives. Thus, each food can gain deeper meanings that need to be decoded through considering the experiences of female characters in fictional works. 
Researches on food are not only studied in the fields of health or nutrition but also conducted in different study fields as literature, psychology, culture and so on. Food is at the centre of our lives and "articles on food have recently appeared in a diverse list of scholarly periodicals and anthologies, while new books on the topic continue to be published in ever greater numbers by both university and trade presses" (Avakian and Haber, 2005: 1). Food in this paper is analysed from a literary perspective focusing on the importance of food and culinary duties in the lives of female characters and their moods. Accordingly, a postmodern feminist perspective was implemented while deconstructing the traditional considerations regarding women's roles in the kitchen. From a traditional perspective, cooking and culinary tasks may not be more than a daily obligation for nourishment. However, this consideration is deconstructed, and foods, cooking, and culinary tasks are reinterpreted. Food has a vital role in the process of maintaining a healthy life for all living beings. However, in literature, it has been revealed that food has become more than nutrition in the lives of fictional characters. In various literary works, "food is memory, food is irony, food is drama, food is symbol, food is form" (Shahani, 2018: 3) while narrating the events. Through the multi-faced nature of food and foodways implemented in literature, readers can reveal a great range of meanings and "by examining the what, where, how, and why of our food choices and food habits, we develop a better understanding of ourselves and others" (Almerico, 2014: 1). Paying attention to the details of foods and their preparations in fictional works might help to detect a more complex interaction between foods and feelings of female characters. Moreover, foods can offer these characters the opportunity to express themselves. In this regard, it can be stated that foods can be represented as a new way of communication in postmodern feminist literary works because foods become the words of female moods. Additionally, food becomes the "secret language of a female psyche shaping a new female narration" (Ayan, 2012: 74) expressing the repressed feelings and moods of women. Furthermore, in literary works, food can even become a character that influences the events and the characters together with functioning as a messenger that informs the reader about the emotions of a person who deals with culinary tasks.

The relationship between food and female identity has become one of the various issues discussed by postmodern feminist literary critics. Avakian and Haber (2005) state that "feminists organized around housework and women's studies scholarship addressed domesticity, but cooking was ignored as if it were merely a marker of patriarchal oppression and, therefore, not worthy of attention" (2). The changing focus of feminist criticism and the dynamic nature of food lead to a variety of interpretations while analysing literary works and "much of the criticism scrutinizing how women use food references dates from the 1980s as do many pertinent literary works, probably because of contemporaneous changes in feminist focus" (Blodgett, 2004: 264). With the deconstruction of the thought that cooking is a restrictive daily obligation for women, the postmodern feminist perspective came to the forefront in the reinterpretation of the relationship between culinary issues and gender roles. This reinterpretation demonstrates that food and culinary duties provide opportunities for creative representations in literature, and traditional gender roles are resisted and reconstructed through foods. Women writers and critics have created a great number of works contributing to literature with an original perspective related to food and identity. The symbolism in most of the contemporary literary works is not limited to the traditional representations of culinary tasks. As a result, authors can benefit from the diversity and abundance of food representations and use it while composing literary works on various social, political, religious, ethnic, national, and cultural issues.

According to Fraser and Nicholson (1988), a postmodern-feminist form of critical inquiry "would be the theoretical counterpart of a broader, richer, more complex, and multilayered feminist solidarity, the sort of solidarity that is essential for overcoming the oppression of women in its "endless variety and monotonous similarity"'”'(102). Rather than rejecting doing culinary tasks in line with a modern feminist point of view, the female characters perform these tasks as a preference in their daily lives since the process of realizing these tasks are not considered as an obligation of patriarchy when considered from a postmodern feminist perspective. In the novel, Rose and her mother have multiple interactions with foods and culinary tasks that unite domestic, personal, and professional experiences of these female characters. Since postmodern feminism strives to deconstruct the grand narratives of the past enforcing a male-dominated essentialist perspective, this deconstruction inevitably leads to plurality of meaning while analysing the texts through a postmodern feminist lens. The point is that postmodern feminist criticism underlines and allows for diversity in meaning that can be deduced from literary 
texts. Bender implements a different form of communication in the novel in which foods substitutes for words through which female characters express their feelings and also sense the feelings of other people. Showalter (1993) claims that

women's writing should be rule breaking ... women should remake language and write in the Mother Tongue. Yet if women choose a literary career, they cannot afford to renounce tradition, the formal resources of language, the rules of the marketplace, the test of aesthetic standards. The metaphors of the matriarchal tradition, which were necessary to inspire scholars and critics working against the critical tide, can now be historicized themselves as the literature becomes established (115).

As such, Bender (2010) encodes meanings to foods which become crucial agents for representing female characters and reinterpreting the role of food and culinary tasks in the lives of the mother and the daughter in the novel. Bender's narrative technique does not fit into the rules of traditional narrative frame of realism, and the metaphors of food and culinary tasks are revealed as a postmodern feminist implementation while creating the text portraying the experiences of female characters that have a close relation with selecting, preparing, cooking, and eating food; and sensing and expressing feelings.

The definition of postmodernism and the specific notions regarding postmodern theory are still being discussed. Considering the relationship between postmodernism and feminism, it can be stated that "many feminist writers have directed their attention towards reframing postmodernist debates in ways which retain feminism's critical edge while rejecting notions of objectivity and all pervasive truth claims" (Fawcett and Featherstone, 2000: 5). Accordingly, it can be said that there is a common point that causes a link between postmodernism and feminism. That is to say, both postmodernism and feminism question and reject the features accepted as universally valid concepts that have been set by patriarchal social structures. Accordingly, the points deconstructed in this novel are the thoughts that the relationship between food and women is based only on nutritional purposes and women are felt imprisoned in the kitchen to carry out the culinary responsibilities. These traditional responsibilities have been defined in fictional works so far, and postmodern female writers have been expected to alter these established figures related to the relationship between food and female identity. In her article, Rich (1972) underlines the necessity for looking back to the previous works and analysing these works with a changing critical perspective. She includes herself also into the process of obtaining a refreshing attitude towards literary creations, and in this regard, she (1972) states that "a radical critique of literature, feminist in its impulse, would take the work first of all as a clue to how we live, how we have been living, how we have been led to imagine ourselves, how our language has trapped as well as liberated us; and how we can begin to see- and therefore live-afresh" (18). Rich (1972) also asserts that the awakening of women would lead them to revise and scrutinize the pre-established norms and expectations regarding a literary work. Refreshing the dictated knowledge through their own perceptions enables women to transgress the limitations drawn by maledominated backgrounds. Regarding this, it can be claimed that "re-vision- the act of looking back, of seeing with fresh eyes, of entering an old text from a new critical direction- is for us more than a chapter in cultural history: it is an act of survival" (Rich, 1972: 18). In line with these comments, one of the deconstructed and reformulated issues related to women can be shown as the role of food and culinary duties in the lives of women. The outcome of this attempt has been the possibility to reveal that food preparation and culinary tasks in the kitchen might liberate women from the daily struggles oppressing them both socially and psychologically. Namely, culinary duties are not a source of restriction for women any longer, but they offer opportunities for liberation in postmodern feminist texts. Postmodern feminism focuses on the interaction between women's lives and their choices and preferences. That is to say, the female liberation is possible as long as women can make their own choices and preferences as autonomous individuals. This consideration of the postmodern feminist perspective is reciprocated in the kitchen, the heart of a home. Women enter kitchen in order to have a pleasant time while dealing with culinary issues. It is inferred that all the steps of culinary tasks are performed with the women's free will, and this is also one of the main points connecting the postmodern feminist perspective with foods.

Finally, another specific notion is that ambiguity and fragmentation are the features revealed in postmodern literature, and deconstruction of predetermined rules and roles is another point demolishing the certainty 
of various social frameworks. According to Avakian and Haber (2005), "particularly within the context of the postmodern questioning of reality[ies], looking closely at the material culture of the food of ordinary people has the appeal of the concrete within a world of uncertainty" (1). In line with this statement, analysing the influence of food and culinary issues on the lives of people, especially the women characters of this novel, may enable to acknowledge the importance of foods that goes beyond the traditional definitions related to nutrition. The ambiguity and fragmentation of meaning attributed to foods provides various opportunities for interpreting literary works from changing perspectives. Moreover, the deconstruction of women's roles and also the rules related to the women's daily lives is one of the points underlined by postmodern feminism. Although predetermined patriarchal notions restrict women and do not allow them to make their own decisions, women can overcome these troubles and realize their self-worth and dignity by making their own preferences and choices with their free will. Since they feel restricted and split within the traditional norms, women pursue the pre-established standards of patriarchy and remain voiceless even when there is something related to their own lives. Postmodern feminist works have deconstructed these considerations by emphasizing women's freewill and independence. That is to say, the more the females pursue their own choices and preferences, the less the ambiguity and fragmentation are present for them.

\section{SENSING THE FEELINGS, REJECTING THE FEEDINGS}

The Particular Sadness of Lemon Cake (2010) written by Aimee Bender is a multi-generic novel that combines postmodernism, feminism, and magic realism. Divided into four parts, the novel is forty-seven chapters in length. One of the central points of the story is the extraordinary ability of Rose Edelstein who is the protagonist of the story. When Rose is nine years old, some important changes start to take place in her life. These changes are closely related to food and affect Rose both physiologically, psychologically, and emotionally. Rose loves lemon cake and her mother, Lane, cooks this cake for her ninth birthday. The selection and preparation steps of the cake are performed with pleasure not only by Rose but also by her mother who starts spending most of her time in the kitchen after quitting her job. Rose says "my birthday cake was her latest project because it was not from a mix but instead built from scratch- the flour, the baking soda, lemon-flavored because at eight that had been my request; I had developed a strong love for sour" (Bender, 2010: 9). She adds "we'd looked through several cookbooks together to find just the right one, and the smell in the kitchen was overpoweringly pleasant" (Bender, 2010: 9). Everything goes well until the delicious taste of the lemon cake leaves its place to an indefinable reaction in Rose's mouth. From the first bite, she feels the hollowness but cannot understand the reason of this taste. For her "the goodness of the ingredients- the fine chocolate, the freshest lemons- seemed like a cover over something larger and darker" (Bender, 2010: 9). She tries to find out the real reason for this shocking difference and checks the quality of the ingredients of the cake. After a while, she associates this unusual case with her mother's emotional state. She realizes that "the lemon and chocolate were just surrounding a hollowness" (Bender, 2010: 10), and the source of this feeling of hollowness is related to her mother and her emotions. She desperately thinks that "my mother's able hands had made the cake, and her mind had known how to balance the ingredients, but she was not there, in it" (Bender, 2010: 10). Rose becomes aware of the fact that she can feel the emotions of her mother by tasting the lemon cake prepared by her mother. She realizes that her mother is unhappy although she does not reflect her sadness to the people around her.

Lane suffers from a kind of emotional hunger since she is not happy with her job. Rose expresses that "she'd been working as an office administrator, but she didn't like copy machines, or work shoes, or computers" (Bender, 2010: 5). She carries out this job in order to contribute to the family income but she desires to do a more "practical" work to "learn to do more with her hands" (Bender, 2010: 5). Due to her unsatisfactory job, Lane feels restricted and is in search of a solution which will fill the emotional hollowness adversely affecting her life. The desire for realizing herself leads Lane to quit her job that does not satisfy her professionally and practically. Putting an end to this unfavourable job may help Lane overcome the emotional dissatisfaction that she suffers from. However, there is also another problem causing the sadness and discontent that Lane experiences. The reason of this trouble is related to her marriage. It can be inferred that the Edelstein family does not have an intimate familial atmosphere and they do not develop a healthy communication between each other. The communication gap can be shown as the source of the problem that hinders a warm family environment in the 
novel. Although the family spends time together at least while they are having dinner, they do not communicate with each other most of the time. Rose narrates:

I read a study, Dad said, flaring his napkin into his lap. Families that eat dinner together are happier families, he said.

I think those families also talk to each other, I said.

Mom, behind us, spooning up a vegetable, laughed (Bender, 2010: 93).

In the novel, one of the formulas of happier families is revealed as eating together with the whole family members. However, the family members of the novel cannot be successful in building up healthy communication. Rose says "it was true: our dinners, always at the table, framed by floral-print kitchen curtains and the rising steam off casserole dishes, were almost always silent in those days..." (Bender, 2010: 93). It is seen in the novel that there is a communication problem in the Edelstein family, and when the female characters are considered, Rose's mother does not pour out her thoughts, desires, and feelings verbally, and the emotional distress causes her to suffer from insomnia as well. She speaks about daily events but she is silent when the issue is her own feelings; however, food that she prepares substitutes her words. She is not aware of this fact but the extraordinary talent of Rose comes to the forefront in the revelation of the repressed feelings. She unveils the inner world of her mother and this is a very devastating experience for the little girl. Tasting the lemon cake that she loves before is the starting point of the process in which food functions as an agent transmitting information about the hidden emotions, desires, and fears of the mother.

Lane is in search of some means to overcome the hollowness that she is in and kitchen is the first place where she can carry out various culinary tasks. Cooking is more than a daily obligation for Lane since she takes pleasure in preparing food that enables her to feel more satisfied. She tries changing recipes and serves the prepared meals with enthusiasm. However, she is not aware of the fact that the meals she prepares reflect not only the feeling of hollowness but also any kind of feeling that she experiences including sadness, happiness, guilt, and so on. It is seen in the novel that Lane has a secret love affair which causes her to split between the life that she has and the life that she desires. When Rose is twelve years old, she becomes aware of the fact that her mother has a secret love affair. She senses this affair when she eats roast beef and potatoes prepared by her mother. Rose states that she "got such a wallop of guilt and romance in my first mouthful that I knew, instantly, that she'd met someone else" (Bender, 2010: 92). While she is occupied with detecting other features of these foods, she assembles the pieces together and finds out the name of the man with whom her mother has an affair. Lane speaks about the carpenters working at the same carpentry where she works. As Rose narrates, Lane comments about each one of these carpenters and the tone of Lane's voice changes immediately when she speaks about one of these carpenters. The obvious change in the tone of voice fits well with the taste of roast beef and potatoes. It does not take much time for Rose to connect these two signs with each other and find out the name of that man. It can be inferred that the ingredients used by Lane cause different tastes that are shaped in line with her emotional status. Here, Rose is the one who realizes the indefinable case related to her mother's meals and tries to find out the reason of this extraordinary experience starting from her ninth birthday. Although her mother loves cooking, Rose avoids eating the meal prepared by her. The reason for avoiding her mother's meals is that the more she consumes her mother's meals, the more she learns about her mother's unspoken world.

The reason of the unusual tastes in the lemon cake and other meals cooked by her mother are related neither with their recipes nor the ingredients. When the particular lemon cake is reconsidered, it is seen that Rose detects that there is a close relation between the taste of the cake and the feelings of the cook, Lane. As a result of this incidence, Rose's focus turns absolutely on the interaction between the foods and moods especially when she eats something prepared by her mother. It does not take much time for Rose to start deciphering the feelings of her mother. This is a very striking experience for the young protagonist, and she knows the changing feelings of her mother whenever she tastes the meals prepared by Lane. It is understood that Lane's emotions caused stress for Rose because the innocent mother and daughter relationship becomes a much more complex one. Lemon cake is normally a combination of sour and sweet tastes, and it is generally acceptable to have a kind of freshness aftertaste when somebody eats it. However, this is not the case for the protagonist of this story. 
Although she states that it is her own wish to have a lemon cake due to its sourness that she desires, this taste turns to be a disturbing reality for Rose. Namely, the sourness metaphorically represses the sweetness of this particular lemon-flavoured cake. As such, the innocent feelings of the daughter are repressed by the complex feelings of the mother. As a result of this undesirable taste in which something deeper is hidden, Rose cannot eat this cake same as before. Her ninth birthday is the last time that she eats lemon cake and her attitude towards this particular kind of cake changes drastically. The sourness becomes unbearable for Rose immediately after she realizes that the reason of this taste is her mother's unhappiness, and she also learns her mother's secret affair in the following years. In order not to be influenced by the hidden feelings of Lane, Rose rejects consuming not only this particular cake but also any other meals prepared by her mother. This attitude may be regarded as a reaction of Rose to her mother's actions. It is claimed that "food choices expose a group or a person's beliefs, passions, background knowledge, assumptions and personalities" (Almerico, 2014: 4). Rose chooses fabricated food rather than the food prepared by her mother. At the background of this preference lies the talent of sensing the unspoken feelings through foods. The emotional turmoil experienced by Lane is expressed by the combination of the ingredients that she uses while cooking and these feelings are sometimes so powerful that Rose cannot bear sensing them.

Bender implements food as a character conveying messages and unveiling the secrets by standing for the unspoken words of the mother in the novel. Thus, the voiceless mother can be heard through food voice that expresses her hidden feelings and thoughts. It is pointed that "while sometimes the food voice is loud and clear, in many instances, that voice is unheard, drowned out in a din of louder messages, or simply not perceived as carrying the power to communicate" (Long, 2004: 119). However, Lane's voice conveyed through her meals is heard by Rose with her talent in sensing feelings through food. As a mother, Lane may strive to protect her children from the emotional distress that she undergoes since she does not reflect her sadness or discontent to the people around her. She does not pour out her deeper feelings or express her thoughts openly. However, with a cosmic irony, the mother who is unreachable until the ninth birthday of Rose becomes a reachable mother for the daughter with the particular lemon cake. No matter how discreet the mother is, the young daughter can sense even the most private feelings of her. Thus, the relationship between the mother and the daughter turns to a tasty one converting from sweetness to sourness. As a result, this cake has a particular role in this transformation in which innocence ends unexpectedly and consequent emotional distance becomes a barrier between the mother and daughter. The extraordinary ability of Rose comes to the forefront while revealing her mother's unspoken feelings provided through the literary technique implemented by Bender. The author mingles the magic and reality proficiently while narrating this transformation and the ensuing events. The foods and culinary tasks of daily life become an instrument for expressing and sensing the unheard voice of females. Demolishing the definitions and binary oppositions of a patriarchal structure that have caused the oppression of women has become a crucial target of postmodern female writers who have rewritten the pre-established social and cultural definitions regarding women since "privileging women's experiences is a response to these experiences being silenced and misconstrued" (Yadav and Yadav, 2018: 59). The voiceless mother's emotional world is represented trough the meals, and her feelings transgresses the borders of restrictions put by patriarchal social order.

The lemon cake turns her life upside-down since Rose becomes aware of the fact that she senses the emotional conditions of other people preparing the food that she consumes. The case of being able to feel people's emotions is an unusual reality for Rose at the beginning of the novel. As time passes, she refrains from consuming homemade food and prefers packaged food. The reason for this preference is the fact that this type of food does not convey feelings. In the following chapters, it is also learned that although she prefers fabricated food, she can even know the features of any kind of packed food when she consumes it. One day at the cafe, she gives information about the details of the food that she eats there. She tastes different kinds of food including eggs, butter, and nutmeg. After tasting them, she says that "the eggs are from Michigan...The butter is French butter...Not pasteurized...The parsley is from San Diego" (Bender, 2010: 271-272). Her extraordinary ability enables Rose to detect the place where the food is produced. She can also know whether the food is organic or not. When she is asked about the quality of ham she eats, she declares that it is an organic product that can be 
understood "in the aftertaste" (Bender, 2010: 272). Her senses enable Rose to detect the details of any kind of food that she tastes.

Varghese (2018) suggests that "when someone is in a happy mood, the food he/she prepares would possess the goodness and delicacy in it. But if it is cooked in blue, it lacks the delicacy and tanginess. One cannot make a perfect dish, if he/she is in a rage or disillusionment" (434). In this regard, Bender provides readers with an outstanding portrayal of the interaction between food and feelings such as the moment when Rose thinks that "I ate an enormous range of food, and mood" (Bender, 2010: 243). At home, she is exposed to the feelings of her mother through the food cooked by her. When she eats something out, she senses the unspoken feelings of other people. It is obvious that food substitute for words in fictional works and various moments support this claim in the novel. One of the vivid examples is that she can reveal the moods of people working in a bakery. George who is the first person believing in her extraordinary ability tries to detect whether Rose can also have information about the moods of other people or she can know the details about different food outside the home. Rose and George do some tests, and the first test is done with some chocolate chips. She informs George about the ingredients of chocolate chips "... the chocolate chips were from a factory, so they had that same slight metallic, absent taste to them, and the butter had been pulled from cows in pens, so the richness was not as full' (Bender, 2010: 61). Then she states that all of these ingredients were mixed and the dough was formed by an angry baker which is confirmed by asking some questions to the baker regarding cookies. It is observed that tasting the hidden feelings of people is an overwhelming issue for little Rose and she becomes very depressed and refrains from eating homemade food. During her school years, she consumes processed food transmitting fewer feelings to feel secure from the dominance of emotions and knowledge.

Although it takes time for Rose to cope with her talent, she starts using this ability in harmony with her daily life. It is obvious that Rose leads her own life as an independent woman by concentrating on the food-related events having a considerable influence on her well-being. She can handle her extraordinary talent in tasting feelings and detecting the features of fabricated foods. Moreover, she begins cooking and spends time with her mother in the kitchen. They select different kinds of recipes from recipe books together. Rose says "twice a week, I cooked for her... For months, we ate only appetizers, and then I moved to soups, and salads, and entrées. I skipped the recipes that sounded too difficult, and my mother picked her favorites and made requests" (Bender, 2010: 278-279). Moreover, Rose decides to work at a cafe where she has satisfying experiences via cooking food in a professional environment. She mentions her decision as "at home, at dinner, l explained to my parents that I would be working part-time at the café, learning about cooking in some form or another...It's not moving out yet, I told them. But it's a step" (Bender, 2010: 283). She makes these important decisions regarding her life through the end of the novel. Rose and her mother start spending more time together in the kitchen trying to overcome the communication problem that can be regarded as the source of the distance between the mother and the daughter. In line with this reconciliation, Rose begins to cope with her talent and engages in culinary tasks. Although she experiences challenges because of her ability, it is seen that she takes crucial steps related to food and nourishment from the beginning till the end of the novel. First of all, she prefers fabricated food rather than homemade food, especially the ones prepared by her mother, in order to refrain from knowing other people's feelings. Then, she starts cooking food at home and serves the prepared meals to her parents. As time passes, she selects recipes together with her mother in the kitchen and engages in culinary tasks meticulously. Finally, she decides working at a cafe where she can help the cafe owners with her talent by detecting the quality of food and ingredients. All these food related steps affect Rose's well-being more positively. By being aware of her food-related talent, Rose continues her life through making her own decisions as an autonomous woman, and this woman puts food into the centre of her life in the process of fostering her self-control, autonomy, selfworth, and dignity.

It can be inferred from the novel that the lack of communication within the Edelstein family might cause stress for the family members, and this can be regarded as one of the key elements that prevents Rose and Lane from realizing their own self-worth and dignity. These two women suffer from this problem deeply and they obviously need to develop strategies to be able to cope with the problem of troubled familial relationships. Additionally, split identities have been frequently encountered themes of literature, and fictional characters can be demonstrated as the ones who are unfortunately torn between traditional and non-traditional roles. In 
the novel, Lane is an unhappy and discontented woman who is split between womanhood and motherhood. She is in search of something that help her gain her own self-worth and dignity. It is pointed that "studying the relationship between women and food can help us to understand how women reproduce, resist, and rebel against gender constructions as they are practiced and contested in various sites, as well as illuminate the contexts in which these struggles are located" (Avakian and Haber, 2005: 2). Examining Lane's interaction with culinary tasks together with analysing Rose's food-related talent can provide clues for understanding how these two women resist against the restrictions that influence them psychologically and emotionally. The first place that Lane prefers is the kitchen where she can enjoy cooking and culinary tasks that will provide her the opportunities for self-fulfilment. In this regard, it is pointed by Shahani (2018) that "in the wake of postmodern tenets that our identities are fragmented and tenuous, food becomes the only remaining marker of selfhood" (10). In the novel, cooking and dealing with food-related tasks cause a kind of relief for the mother and daughter. As it is seen, "evocations of food in literature enrich the reading experience, providing a tangible link to the imaginary world of the text" (Boyce and Fitzpatrick, 2017: 292). Food is in the centre of the lives of both Rose and her mother with its additional features leading to extraordinary events in the fictional world through which the accuracy of meaning can be questioned and deconstructed. Moreover, food is an instrument for communication and a source for relief for them and becomes an agent to develop a closer relationship between Rose and her mother through the end of the novel. It can be inferred that traditional considerations regarding food and cooking and female's roles as food providers have been deconstructed by the author of the novel through creating a magic realist narrative frame. As it is emphasised by Arva (2008),

typically, readers of magical realist fiction must look beyond the realistic detail and accept the dual ontological structure of the text, in which the natural and the supernatural, the explainable and the miraculous, coexist side by side in a kaleidoscopic reality, whose apparently random angles are deliberately left to the audience's discretion (60).

Accordingly, it is seen that together with its importance for survival, food has also been reflected as a valuable factor for developing a sense of self, maintaining healthy social and psychological interaction with other people, and having an autonomous identity. Moreover, the culinary tasks are not a source of restriction for the female figures in the novel. Namely, these tasks become more than obligatory duties to be fulfilled. The kitchen does not imprison women but it becomes a place for experiencing relief while following the steps related to food and cooking. In the novel, it is seen that Lane is the first female character who cooks various kinds of meals for her family with great enthusiasm. It can be understood that Lane finds relief while cooking meals since this task enables her to engage in productive and practical activities through which she can develop a sense of personal fulfilment. Moreover, the relationship between Rose and culinary tasks does not also fit into the traditional standards. Dealing with food-related tasks is not an obligation but a preference for Rose. Following that she acknowledges her talent as an agent for empowerment, Rose utilises this ability on behalf of her personal and professional development.

\section{CONCLUSION}

The Particular Sadness of Lemon Cake (2010) is a multi-generic novel and thus multiple perspectives can be integrated while analyzing the novel. Bender is one of the writers who demolish the standards of classical literary tradition and presents a story in which a crucial interaction between foods and feelings of females is depicted with a non-traditional narrative technique. This study has evaluated the combination of magic realism and postmodern feminism in the process of presenting the relationship between feelings of the female characters and the foods prepared or served by these women in the novel. In postmodern feminist approach, the choices and preferences of women come into prominence. Accordingly, a vital continuity is represented while Rose takes important decisions affecting her life substantially. The decisions taken and the choices made by Rose in the kitchen are decisive for her physiological, psychological, and emotional well-being. In this regard, foods deserve critical attention because they can be regarded as an excellent mean to contextualise the females' experiences reflected in the novel. It has been detected that the most outstanding preferences of Rose are related to food and culinary issues due to her talent in sensing the feelings of other people by tasting the food prepared or 
served by them. As a result of this study, it has been concluded that Bender as a contemporary female writer deconstructs the traditional images regarding the females' roles in the kitchen.

Moreover, the author also demonstrates that food is more than nutrition by representing various incidents related to the role and importance of food in females' lives. It is detected that food and culinary issues are implemented as factors that are beyond nutritional facilities in the novel. Bender does not use food and culinary tasks from a single perspective in the narration. However, she utilises these agents in different forms for revealing unspoken feelings, thoughts, or facts. The mother's feelings are coded in foods and these feelings are decoded by the daughter. Coding and decoding of feelings are provided through foods in the novel. Tasting and preparing food have been transformed into interpersonal communication agents utilised when the characters cannot communicate through words. Furthermore, the communication problem among people has also disrupted interpersonal relations and affected family togetherness negatively. To overcome this problem, Rose and her mother have unconsciously put food almost into the centre of their lives. Thus, food for nourishment has transformed into food for communication, food for relief, and food for personal development.

It is also seen that there is a very intricate relationship between foods and feelings of the protagonist and her mother in the novel. The magic and reality is mingled such a way in the novel that food is not only for nourishment but also for expression, emotional satisfaction, and self-realization for the female characters. The mother's interaction with food is one of the points examined in detail for revealing her unconscious attempts for coping with the encountered problems and detecting the reasons that cause her to cook food in changing emotional states. It is seen that Lane is split between womanhood and motherhood, and this case causes dissatisfaction and unhappiness in her life. In order to find as place for self-fulfilment, she unconsciously prefers kitchen where she can develop a sense of satisfaction through dealing with culinary issues. Lane has a secret affair which is sensed by Rose through tasting the meals prepared by her mother. This secret affair leads an emotional distance between the mother and the daughter at first. However, it is seen through the end of the novel that Rose does not judge or blame her mother due to her secret love affair and the distance between Rose and Lane starts narrowing especially with the culinary tasks that they performed together in the kitchen.

The complex personal relationships have enriched the meanings attributed to food and culinary tasks. Food and women's roles in the kitchen reflected in literary works have become more than the traditional considerations limiting the female creative potential. The novel shows that the crucial point is that women have not felt restricted in the kitchen but they have gained self-esteem and felt more satisfied with their lives. Involving in culinary tasks enables female characters to express themselves freely in the process of preparing meals. In accordance with the postmodern feminist concerns regarding the criticism of the grand-narratives of the patriarchal social structure, it can be underlined that the culinary duties undertaken frequently by females should be reinterpreted from a changing perspective which has not been affected from the pre-established masculine norms. Consequently, alternative interpretations regarding foods would be one of the points attracting the attention of scholars.

In The Particular Sadness of Lemon Cake (2010), food is something more than nutrition. Food is a secret language narrating the repressed feelings and mean of communication enabling female characters to realize the hidden feelings that shape their moods. Accordingly, the relationship between foods and moods of females has been the focal point in this study. Further studies on Aimee Bender's The Particular Sadness of Lemon Cake can be conducted on the issue of eating disorders that Rose experienced or on the reflections of packaged food and homemade food consumption in the postmodern era. 


\section{REFERENCES}

Almerico, G. M. (2014). “Food and Identity: Food Studies, Cultural, and Personal Identity”, Journal of International Business and Cultural Studies, 1-8.

Arva, E. L. (2008). "Writing the Vanishing Real: Hyperreality and Magical Realism". Journal of Narrative Theory, 38/1, 60-85.

Avakian, A. V. and Haber, B. (2005). "Feminist Food Studies: A Brief History", From Betty Crocker to Feminist Food Studies: Critical Perspectives on Women and Food, (Ed: A. V. Avakian and B. Haber), University of Massachusetts Press, United States of America.

Ayan, M. (2012). Diversities in Ethnic Female Narratology. İkinci Adam Yayınları, İstanbul.

Barthes, R. (2013). "Toward a Psychosociology of Contemporary Food Consumption", Food and Culture, (Ed: C. Counihan and P. Van Esterik), Routledge, New York and London.

Bender, A. (2010). The Particular Sadness of Lemon Cake, Anchor Books, New York.

Blodgett, H. (2004). “Mimesis and Metaphor: Food Imagery in International Twentieth-Century Women's Writing", Papers on Language and Literature, 40/3, 260-295.

Bortolussi, M. (2003). "Introduction: Why We Need Another Study of Magic Realism". Canadian Review of Comparative Literature/Revue Canadienne de Littérature Comparée, 30/2, 279-293.

Boyce, C. and Fitzpatrick, J. (2017). A History of Food in Literature: From the Fourteenth Century to the Present, Routledge, London and New York.

Cixous, H. (1976). "The Laugh of the Medusa". Signs, 1/4, 875-893.

De La Campa, R. (1999). “Magical Realism and World Literature: A Genre for the Times?”, Revista Canadiense de Estudios Hispánicos, 23/2, 205-219.

Ebert, T. L. (1991). “The “Difference” of Postmodern Feminism”, College English, 53/8, 886-904.

Fawcett, B. and Featherstone, B. (2000). "Setting the Scene: An Appraisal of Notions of Postmodernism, Postmodernity, and Postmodern Feminism", Practice and Research in Social Work: Postmodern Feminist Perspectives, (Ed: B. Fawcett, B. Featherstone, J. Fook and A. Rossiter), Routledge: London and New York.

Fraser, N. and Nicholson, L. (1988). "Social Criticism without Philosophy: An Encounter between Feminism and Postmodernism". Universal Abandon? The Politics of Postmodernism, (Ed: A. Ross), University of Minnesota Press, Minneapolis.

Henitiuk, V. (2003). "Step into My Parlour: Magical Realism and the Creation of a Feminist Space". Canadian Review of Comparative Literature/Revue Canadienne de Littérature Comparée, 30/2, 410-427.

Long, L. M. (2004). "Learning to Listen to the Food Voice: Recipes as Expressions of Identity and Carriers of Memory", Food, Culture \& Society, 7/1, 118-122.

Rich, A. (1972). "When We Dead Awaken: Writing as Re-Vision”, College English, 34/1, 18-30.

Sands, R. G. and Nuccio, K. (1992). "Postmodern Feminist Theory and Social Work”, Social Work, 37/6, 489-494.

Shahani, G. G. (2018). "Introduction: Writing on Food and Literature", Food and literature, (Ed: G. G. Shahani), Cambridge University Press, United States of America.

Showalter, E. (1984). “Women's Time, Women's Space: Writing the History of Feminist Criticism”, Tulsa Studies in Women's Literature, 3(1/2), 29-43.

Showalter, E. (1993). “American Gynocriticism”, American Literary History, 5/1, 111-128.

Trivedi, K. (2013). "Magic Realism: A Genre of Fantasy and Fiction", International Journal of English and Education, 2/3, 389-393.

Varghese, A. (2018). "Food as Image in Literary Criticism", International Journal of English Language, Literature in Humanities, 6/9, 428-436.

Vidal, M. C. Á. (1991). “Towards a Postmodern Feminism?”, Atlantis, 12/2, 83-93.

Yadav, M. S. and Yadav, M. K. (2018). “Aspects of Feminist Writing: A Presentation of Common Issues”, Journal of English Language Teaching and Linguistics, 3/1, 57-68. 


\section{Beyan ve Açıklamalar (Disclosure Statements)}

1. Bu çalışmanın yazarları, araştırma ve yayın etiği ilkelerine uyduklarını kabul etmektedirler (The authors of this article confirm that their work complies with the principles of research and publication ethics).

2. Yazarlar tarafından herhangi bir çıkar çatışması beyan edilmemiştir (No potential conflict of interest was reported by the authors).

3. Bu çalışma, intihal tarama programı kullanılarak intihal taramasından geçirilmiştir (This article was screened for potential plagiarism using a plagiarism screening program). 